\title{
A D-TÍPUSÚ SZEMÉLYISÉG SKÁLA PSZICHOMETRIAI JELLEMZÖI REPREZENTATÍV VIZSGÁLAT ALAPJÁN
}

\author{
PUREBL GYÖRGY1* - RÓZSA SÁNDOR² - \\ DANIS ILDIKÓ ${ }^{3}$ - KOPP MÁRIA ${ }^{1}$
${ }^{1}$ Semmelweis Egyetem, Magatartástudományi Intézet, Budapest ${ }^{2}$ ELTE PPK, Pszichológiai Intézet, Személyiség- és
Egészségpszichológiai Tanszék, Budapest
${ }^{3}$ MTA Pszichológiai Kutatóintézet, Budapest

(Beérkezett: 2006. július 18.; elfogadva: 2006. július 25.)

\begin{abstract}
Jelen vizsgálat célja a D-típusú személyiség vizsgálatára kifejlesztett kérdôív magyar adaptációja volt. A D-típusú (distressed) személyiség modelljét számos vizsgálat alapján a szívés érrendszeri betegségek fontos kockázati tényezójének tartják. A Hungarostudy 2002 országos reprezentatív vizsgálat keretében 12653 személlyel került felvételre a mérôeszköz. A kérdőív magyar változatában 4 tétel rontotta a kérdôív pszichometriai jellemzóit, így ezeket a tételeket kihagytuk a kérdőívból, amely így 10 kérdésre redukálódott. A 10 kérdéses változat Cronbach-alfa értékei már mindkét skálára kielégítónek bizonyultak (Negatív Érzelmek skála: 0,87; Szociális Gátoltság skála: 0,84). Az elvégzett faktoranalízis megerősítette a magyar változat kétfaktoros struktúráját, így a skála magyar verziója megfelelően alkalmas a D-típusú személyiség vizsgálatára.
\end{abstract}

Kulcsszavak: D-típusú személyiség, 10 tételes D-típusú Személyiség Skála, pszichometriai jellemzók

Számos pszichológiai tényezőt kapcsolatba hoztak már a kardiovaszkuláris morbiditással és mortalitással (Rozanski és mtsai 1999), azonban - bár számos bizonyíték áll rendelkezésre különböző személyiségjegyek, pszichológiai állapotok vagy pszichés zavarok befolyására a szív-és érrendszeri betegségekre - átfogó konceptuális modellel nem rendelkezünk a pszichológiai tényezók, valamint a szív- és érrendszeri betegségek kapcsolatáról.

Egy érdekes kísérlet a pszichológiai faktorok lehetséges közös mozzanatainak egy modellben való egyesítésére a D-típusú személyiség elmélete,

\footnotetext{
* Levelező szerző: Dr. Purebl György, Semmelweis Egyetem, Magatartástudományi Intézet, 1089 Budapest, Nagyvárad tér 4. E-mail: purgyor@net.sote.hu
} 
melyet Johann Denollet és munkatársai alkottak meg (Denollet és mtsai 2001). A modell szerint a kardiovaszkuláris rizikót fokozó pszichológiai tényezók közös jellemzói a gyakori negatív érzelmek, és a szociális gátoltság, melyek magas hétköznapi stressz-szintet eredményeznek. Ezeket a jellemzóket a szerzók a szív- és érrendszeri betegségekre pszichológiai okokból hajlamos személyek két fő központi vonásaként határozták meg.

Számos vizsgálat bizonyította a D-típusú személyiség és a rosszabb prognózis kapcsolatát mind myokardiális infarktuson átesett, és infarktuson még nem átesett koronária-betegeknél (Denollet és mtsai 1995, 1996, 1998, 2000; Pedersen és mtsai 2003).

A D-típusú személyiséget kiterjedten vizsgálják Európában. A vizsgálatára kifejlesztett kérdő́ivnek számos, különbözó hosszúságú változata van (24, 16 és 14 tételes verziók). A különbözó nyelvre lefordított és adaptált változatok fố törekvése a nyelvi/ kulturális különbségek figyelembevételével az egyes változatok pszichometriai tulajdonságainak optimalizálása volt, és nem az eredeti kérdőív változatlanságának feltétlen védelme (Habra és mtsai 2003; Pedersen és mtsai 2000; Denollet és mtsai 1998, 2000).

\section{CÉLKITÚZÉSEK}

Jelen vizsgálat célja a kérdőívnek a D-típusú személyiség magyar nyelvú vizsgálatára alkalmazható adaptációja volt.

\section{MINTAVÉTEL}

Az adatfelvétel a Hungarostudy 2002 országos felmérés keretében történt. A felmérés életkor, nem és lakhely szerint a teljes magyar felnótt lakosságot reprezentálja. A kérdóívcsomagot, melynek része volt a D-típusú Személyiség Skála is, 12653 személy töltötte ki. A visszautasítási ráta a teljes kérdóívre átlagosan $17,6 \%$ volt, mely alacsonynak mondható (Rózsa és mtsai 2003). A D-típusú Személyiség Skálát 11122 vizsgált személy válaszolta meg értékelhetôen.

\section{A D-TÍPUSÚ SZEMÉLYISÉG SKÁLA MAGYAR VÁLTOZATÁNAK KIFEJLESZTÉSE}

Az eredeti, 14 tételes változatot a három független fordító magyarra fordította, majd a közösen kialakított verziót egy angol anyanyelvú fordító visszafordította angolra. Az eredetivel így összevetett fordításból alakí- 
tottuk ki a magyar változatot. A Hungarostudy többi kérdéséhez való jobb illeszthetôség miatt az eredetileg 5 fokozatú skálát a Hungarostudyban általánosan használt 4 fokozatú skálává alakítottuk át. A magyar változat a külföldiekhez hasonlóan két skálát tartalmaz: Negatív Érzelmek skála (NA) és Szociális Gátoltság skála (SI). A fentiek szerint átalakított skálán azok tekinthetók D-típusú személyiségnek, akik mindkét skálán 3 vagy több pontot értek el.

\section{A SKÁLA PSZICHOMETRIAI ELEMZÉSÉNEK EREDMÉNYEI}

\section{Belsố konzisztencia}

A kérdôív belsó konzisztenciáját vizsgálva azt találtuk, hogy a Cronbachalfa érték az NA és SI skálákra 0,88 és 0,76, amely az NA skála esetében megfelelóen magas érték, az SI skála esetében viszont enyhén elmarad a külföldi, 14 tételes D-típusú Személyiség Kérdőívek értékeitól.

Az SI skála viszonylag alacsonyabb belsó konzisztenciájának hátterében azt találtuk, hogy a két, fordítottan kódolandó kérdésre adott válaszok gyakorlatilag véletlenszerú eloszlást mutatnak. Ezért ezeket a kérdéseket, valamint az NA skála belsó konzisztenciát leginkább gyengító két kérdését kihagytuk, és így egy 10 tételes skálát kaptunk, melynek öt kérdése a szociális gátoltságra (SI), öt kérdése a negatív érzelmekre (NA) vonatkozik. Az így kapott skála pszichometriai mutatói lényegesen jobbnak bizonyultak. A Cronbach-alfa érték az NA és SI skálákra 0,87, illetve 0,84-re változott. Faktoranalízissel jól elkülönült a két skála, és kiraj-

1. táblázat. A D-típusú Személyiség Skála magyar változatának faktorstruktúrája Varimax rotációval végzett főkomponens-analízis segítségével

\begin{tabular}{|l|c|c|}
\hline & Faktor 1 & Faktor 2 \\
\hline Gyakran érzem boldogtalannak magam & 0,76 & \\
Gyakran vagyok ingerült & 0,76 & \\
Gyakran rossz a hangulatom & 0,79 & \\
Sokszor kapom magam azon, hogy aggódok valami miatt & 0,73 & \\
Gyakran magam alatt vagyok & 0,81 & \\
Gyakran érzem magam gátoltnak a társas kapcsolatokban & & 0,63 \\
Nehezen kezdek el egy beszélgetést & & 0,81 \\
Zárkózott ember vagyok & & 0,81 \\
Inkább távol tartom magamtól az embereket & & 0,77 \\
Ha más emberekkel vagyok együtt, gyakran nem találom & & 0,70 \\
$\quad$ a megfeleló szavakat a beszélgetéshez & 50,24 & 13,81 \\
\hline Megmagyarázott variancia \% & & \\
\hline
\end{tabular}


2. táblázat. A Negatív Érzelmek és a Szociális Gátoltság Skálák leíró statisztikái

\begin{tabular}{|l|c|c|c|c|}
\hline & Átlag & Szórás & $\begin{array}{c}\text { Ferdeség } \\
(\mathrm{SE}=0,02)\end{array}$ & $\begin{array}{c}\text { Csúcsosság } \\
(\mathrm{SE}=0,04)\end{array}$ \\
\hline Negatív Érzelmek (NA) & 3,30 & 3,32 & 1,22 & 1,13 \\
\hline Szociális Gátoltság (SI) & 2,20 & 2,89 & 1,62 & 2,48 \\
\hline
\end{tabular}

zolódott a kérdôív kétfaktoros struktúrája (1. táblázat). Az NA és SI skálák átlagait a 2. táblázat mutatja be. A nók $27,4 \%$-a, a férfiak 23,5\%-a került a két skála segítségével kialakított D-típusú személyiség kategóriájába.

\section{Validitás}

A továbbiakban megvizsgáltuk a D-típusú Személyiség Skála kapcsolatát a Beck Depresszió Kérdóív rövidített változatával. Az eredményeket a 3. táblázat szemlélteti. A Negatív Érzelmek skála közepesen erôs, míg a Szociális Gátoltság skála gyenge korrelációt mutatott a depresszió mértékével. Elmondható tehát, hogy a számos fenomenológiai hasonlóság ellenére a D-típusú Személyiség Skála és a Beck Depresszió Kérdôív rövidített változata különböző konstruktumokat mér.

Az életkorral mind a Negatív Érzelmek, mind a Szociális Gátoltság skála jelentéktelen korrelációt mutatott (3. táblázat).

3. táblázat. Pearson-féle korreláció a D-típusú Személyiség Skála két skálája és a Beck Depresszió Kérdóív rövidített változata között

\begin{tabular}{|l|c|c|}
\hline & BDI & Életkor \\
\hline Negatív Érzelmek (NA) & $0,62^{* *}$ & $0,09^{* *}$ \\
\hline Szociális Gátoltság (SI) & $0,42^{* *}$ & $0,05^{* *}$ \\
\hline
\end{tabular}

\section{ÖSSZEFOGLALÁS}

A 10 kérdésre redukált magyar D-típusú Személyiség Skála pszichometriai mutatói hasonlóak az eredeti, 14 tételes változathoz.

A közepes erôsségú korreláció a Negatív Érzelmek skála és a Beck Depresszió Kérdôív között további magyarázatot igényel. A negatív érzelmek fontos tényezói a depressziós állapotnak, és a vizsgálat keresztmetszeti elrendezôdése nem teszi lehetôvé, hogy kiderítsük: a negatív érzelmek egy aktuális állapot (depresszió), vagy egy tartós személyiség konstruktum részjelenségei-e. Ugyanakkor az a tény, hogy sem az NA, 
sem az SI skála nem mutatott korrelációt az életkorral, nem mond ellent annak a feltételezésnek, hogy a D-típusú jegyek tartós személyiségvonások, szemben a depressziós tünetekkel, melyeknek az életkorral való erôs kapcsolatával kiterjedt szakirodalom foglalkozik. Igen fontos, jövóbeli kutatási feladat lehet tehát a depresszió és a D-típusú személyiség kapcsolatának mélyebb elemzése, illetve az, hogy a tartós személyiség-konstruktumnak tartott D-típusú jellemzók változnak-e egy longitudinális vizsgálatban. Összességében a kérdőív magyar változata megfelelô eszköznek túnik a D-típusú személyiség hazai vizsgálatára.

\section{MELLÉKLET}

\section{A D-típusú Személyiség Skála magyar változata}

Hogyan jellemezné saját magát?

Kérem, válaszoljon az alábbiak szerint:

0. egyáltalán nem jellemző; 1 . alig jellemzô; 2. jellemzô; 3 . teljesen jellemző

1. Gyakran érzem boldogtalannak magam.

2. Gyakran vagyok ingerült.

3. Gyakran érzem magam gátoltnak a társas kapcsolatokban.

4. Nehezen kezdek el egy beszélgetést.

5. Gyakran rossz a hangulatom.

6. Zárkózott ember vagyok.

7. Inkább távol tartom magamtól az embereket.

8. Sokszor kapom magam azon, hogy aggódom valami miatt.

9. Gyakran magam alatt vagyok.

10. Ha más emberekkel vagyok együtt, gyakran nem találom a megfelelô szavakat a beszélgetéshez.

Negatív érzelmek skála: 1, 2, 5, 8, 9

Szociális gátoltság skála: 3, 4, 6, 7, 10

\section{IRODALOM}

Denollet, J., Brutsaert, D. L. (1998): Personality, disease severity, and the risk of long term cardiac events in patients with a decreased ejection fraction after myocardial infarction. Circulation, 97 (2): 167-173.

Denollet, J., Sys, S. U., Brutsaert, D. L. (1995): Personality and mortality after myocardial infarction. Psychosom. Med. 57 (6): 582-591.

Denollet, J., Sys, S. U., Stroobant, N., Rombouts, H., Gillebert, T. C., Brutsaert, D. L. (1996): Personality as independent predictor of long term mortality in patients with coronary heart disease. Lancet, 347: 417-421.

Denollet, J., Vaes, J., Brutsaert, D. L. (2000): Inadequate response to treatment in coronary 
heart disease. Adverse Effects of Type D Personality and younger age on 5-year prognosis and quality of life. Circulation, 102 (6): 630-635.

Denollet, J., Van Heck, G. L. (2001): Psychological risk factors in heart disease. What Type D personality is (not) about? J. Psychosom. Res. 51(3): 465-468.

Habra, M. E., Linden, W., Anderson, J. C., Weinberg, J. (2003): Type D is related to cardiovascular and neuroendocrine reactivity to acute stress. J. Psychosom. Res. 55 (3): 235-245.

Pedersen, S. S., Hermann-Lingen, C., Purebl Gy., Gremigni, P. (2003): Symposium entitled Cross cultural data on the Type D Personality Construct. To be presented at the The Third International Conference on the (Non) Expression of Emotions in Health and Disease, Tilburg, October 19-21.

Rozanski, A., Blumenthal, J. A., Kaplan, J. (1999): Impact of psychological factors on the pathogenesis of cardiovascular disease and implication for therapy. Circulation, 99 (16): 2192-2217.

Rózsa S., Réthelyi J., Stauder A., Susánszky E, Mészáros E, Skrabski Á, Kopp M (2003): A HUNGAROSTUDY 2002 Országos Reprezentatív felmérés általános módszertana és a felhasznált tesztbattéria pszichometriai jellemzói. Psychiatria Hungarica, 18 (2): 283-94.

A tanulmány elkészítését segítô támogatások. A tanulmány az OTKA TS-40889 (2002), a TS049785 (2004), valamint az NKFP 1/002/2001 és az NKFP 1b/020/2004 pályázatok támogatásával készült.

\section{PUREBL, GYÖRGY - RÓZSA, SÁNDOR - DANIS, ILDIKÓ - KOPP, MÁRIA \\ PSYCHOMETRIC PROPERTIES OF THE HUNGARIAN VERSION OF TYPE D SCALE IN A LARGE COMMUNITY SURVEY}

Growing number of studies demonstrate the role of Type D Personality Construct in coronary artery disease. The aim of this study was the Hungarian adaptation of Type D Scale (DSi10). In the Hungarostudy National Representative Community Survey 12,653 people were interviewed, representing the Hungarian population over the age of 18 according to age and sex. The test battery included the Hungarian interview version of the Type D scale and the shortened Hungarian version of the Beck Depression Inventory. Results: Cronbach's a value for both subscale was satisfactory (NA: 0.87, SI: 0.84), the factor analysis confirmed the bifactorial structure of Dsi10. NA explained $50.24 \%$ and SI $13.81 \%$ of the total variance. Conclusions: Dsi10 is a practical and reliable instrument for assessing Type D Personality Construct.

Keywords: Type D personality, 10-item Hungarian version of Type D Scale, psychometric properties 